Article

\title{
Consumer Attitude, Concerns, and Brand Acceptance for the Vegetables Cultivated with Sustainable Plant Factory Production Systems
}

\section{Li-Chun Huang}

Department of Bio-Industry Communication and Development, National Taiwan University, No. 1, Sec. 4, Roosevelt Road, Taipei 10617, Taiwan; lihuang@ntu.edu.tw; Tel.: +886-2-3366-4418; Fax: +886-2-2363-5879

Received: 7 August 2019; Accepted: 2 September 2019; Published: 5 September 2019

\begin{abstract}
Plant factories are perceived as a sustainable agricultural production system, since they provide a cultivation environment for growing agricultural crops with less resource consumption and no pesticide use. However, as the industry and academic participants have been contributing in the development of plant factory technology, consumer acceptance for the crops cultivated from that technology remains unknown. Without consumer acceptance, all the costs spent in the research and development $(\mathrm{RD})$ of plant factories cannot gain the profit. To address this deficiency, this study was aimed to: (1) investigate consumers' attitudes, concerns and willingness to pay for the vegetables cultivated with plant factories, (2) explore the branding mode that is most effective for selling plant factory vegetables to consumers, and (3) determine the influence of consumers' socio-demographics and vegetable purchase behavior for their willingness to pay for plant factory vegetables. With a modified strategy of multi-stage cluster sampling, a consumer survey was conducted and 390 valid questionnaires were obtained for statistical analysis. Data were analyzed with descriptive statistical analysis, analysis of variance, Duncan's post hoc analysis, and regression analysis to meet the study objectives. The study results indicated that over half of the subjects appreciated the value of plant factory technology. However, as high as $64.4 \%$ of the subjects revealed concerns. Most of the concerns were about the issues of environmental pollution and food safety. It also showed that price played a decisive role for consumers' purchase intentions to plant factory vegetables. Moreover, consumers were more willing to pay a higher price for the plant factory vegetables labeled with an allied brand of academic institutes and private corporations, compared with those labeled with other types of brand. Consumers who had higher income and/or consume more organic vegetables were also more willing to pay for the plant factory vegetables. The study findings help the industry participants to build up effective market strategies for selling the crops cultivated with sustainable plant factory systems.
\end{abstract}

Keywords: sustainable agriculture; food safety; analysis of variance; post hoc analysis; regression analysis

\section{Introduction}

Plant factories are agricultural production systems generated from the integration of a wide range of technologies, such as plant physiology, meteorology, machinery, etc. With the support of information technology, modern plant factory systems can be fully artificially controlled to stratify the needs of the growth of various plants that have different biological characteristics [1-3].

The application of plant factories is growing fast in Asia, particularly in Taiwan, Japan, and China. Factors driving the rapid growth of the plant factory industry in Asia are multifold. Food safety is one of the reasons. The happenings of food safety scandals in Asia, such as China melamine milk scandal, food poisoning cases in the South Korea and Thailand, groundwater pollution in South and Southeast Asia, etc., have spurred people to look for safe, high quality food [4-6]. Climate change is another reason. 
Plant factories are an indoor agricultural production system that depends much less on natural resources and is less influenced by the outside climate [7]. Thus, plant factory systems allow farmers to grow quality crops despite the stress of climate change. As East Asia is expected to be one of the regions which will undergo more severe challenges from climate change than other regions [8], some countries in East Asia see plant factories as an approach to cope with climate change.

The plant factory concept has been applied to agricultural production as early as 50 years ago in the West [9]. However, modern plant factories are quite different in the aspects of operation system and installation compared with decades ago. The differences not only make contemporary plant factories become an approach of precision agriculture, but also a sustainable system with several advantages. Firstly, the indoor cultivation systems of plant factories can be completely isolated from the external environment. Thus, the growers can keep that production environment disease-free without using pesticides. Namely, the crops can be completely free from the contamination of pesticide residues, a benefit of food safety greatly appreciated by consumers [10-12]. Secondly, the modern plant factory technology uses an artificial lighting system, such as LED (Light-emitting diode), to improve the growth rate and quality of the plants. With the use of LED lighting systems, lighting intensity and quality can be controlled, thus, the photosynthesis rate of the crops can be optimized to improve the growth rate and quality of the crops. Moreover, LED lighting needs less electricity and has lower heat output compared with the traditional greenhouse lighting systems of high-pressure sodium lamps and fluorescent tubes [9,13-15]. Thirdly, plant factories are equipped with multi-layer vertical growing systems to save the use of lands. The productivity per unit area of land can be greatly increased with the plant factory production systems. Fourthly, plant factories are also a soilless production system where hydroponic irrigation systems are installed to supply water and nutrition to plants. Since the irrigation system is recyclable, the amount of water used for the irrigation in plant factories is only $2 \%$ of the needed of open-field farms [14]. Additionally, with the support of information technology, the operation of plant factories can be computer automated, and thus, the labor force needed for farming with plant factories is much less than that with conventional agricultural approaches [3]. In sum, as water expense, land availability, energy consumption, and labor shortage have become a resource pressure for agricultural production, plant factories make farming possible in extreme climate zones, highly urbanized areas, and those zones with very limited land available for agricultural production in a sustainable way [14,16-19]. It was reported that the productivity of plant factories can be 100 folds compared with that of open filed [7], and 18 times of greenhouse [20].

Besides the advantages described above, the crop production of plant factories can also be scaled up to a mass production independent from the outdoor environment, and thus, the production volume is increased, consistent, and predictable. This advantage is highly appreciated by the food industry, since it allows the supply of plant raw materials to merge into the supply chain of food industry more efficiently.

Even though plant factories are advanced in many ways for being an agricultural production system, some scholars claimed that they have the disadvantage of high cost in initial investment and electricity consumption, as well as lacking cultivation technologies for various crops, as presented in Table $1[7,21,22]$. In particular, their high installation and management costs result in the problem that farmers need to sell the crops of plant factories at a higher price in order to cover the production cost. It inhibits consumers' purchase intentions for the crops cultivated with plant factories. For example, one consumer survey in Japan indicated that price was the main concern for consumers to decide whether they would buy the vegetables cultivated with plant factories [23]. Another Internet survey conducted in Japan with 2000 subjects indicated that most respondents would not buy the vegetables of plant factories unless the price could be equal to or lower than the conventional ones [24]. 
Table 1. The advantage and disadvantage of plant factories.

\begin{tabular}{llll}
\hline \multicolumn{1}{c}{ Advantages } & \multicolumn{1}{c}{ Disadvantages } \\
\hline 1. & Less natural resource (i.e., water and land) needed $*$ & 1. & High cost in initial investment \\
2. & Less labor force needed & 2. & Higher electricity consumption $* *$ \\
3. & Free from pesticide contamination $*$ & 3. & Lacking cultivation technologies for various crops
\end{tabular}

* The advantage of plant factories from the perspective of environmental sustainability; ${ }^{* *}$ The disadvantage of plant factories from the perspective of environmental sustainability.

Plant factories have been considered as a sustainable approach for coping with various stresses in agricultural production, such as climate change and the shortage of natural sources and labor force. However, technology alone is not sufficient to persuade growers to adopt this new production system that profitability is an essential factor [25-27]. However, most of the researchers ignore that and contribute their efforts on the technology-related issues [28-30]. To address this deficiency, this study was aimed to: (1) investigate consumers' attitudes, concerns, and willingness to pay for the vegetables cultivated with plant factories, (2) explore the branding mode that attracts higher consumers' willingness to pay for the vegetables grown with plant factories, and (3) determine the influence of consumers' socio-demographics and vegetable purchase behavior for their willingness to pay for plant factory vegetables. Findings from this study are valuable for developing appropriate strategies to promote the crops of plant factories successfully, which is important for the plant factory industry to gain profits from the market to cover their RD cost, and helpful for the industry to earn more financial support from the investors for continuing the research of sustainable agriculture production systems.

\section{Methodology}

\subsection{Sampling}

The targeted population of this study was the consumers who were 18 years old or older who lived in Taiwan and were really the persons who were responsible for grocery shopping for their households. The strategy of modified multi-stage cluster sampling was applied to ensure the generalizability of the sample. At the first stage, the population was stratified into three clusters based on the geographic difference of their residence, namely the North, Center, and South of Taiwan, which possess differences in lifestyle and social values. At the second stage, each cluster was re-stratified into two sub-clusters, namely urban and non-urban clusters. The population in the metropolises served as the sample pool for urban lifestyles, while the population of counties served as the sample pool for non-urban lifestyles. As a result, the populations of Taipei, New Taipei City, Taichung, Tainan, and Kaohsiung served as the sampling pool for the population who live an urban lifestyle in the North, Center, and South of Taiwan, while the counties of Miaoli, Changhua, Yunlin, and Taitung served as the sampling pool for the population with a non-urban lifestyle in the North, Center, and South of Taiwan. In other words, Taipei City, New Taipei City, and Miaoli County were selected for sampling the urban and non-urban population of Northern Taiwan; Taichung City and Changhua County were selected for the urban and non-urban population for Central Taiwan; Tainan, Kaohsiung, Yunlin County, and Taitung County were selected for the urban and non-urban population of Southern Taiwan (Table 2).

At the fourth stage, a list of vegetable retail channels was made for each targeted city and county by searching on the Internet with the keywords of "traditional market," "supermarket," and "department store", in order to reach the targeted population, and then three vegetable retail channels were randomly selected for each targeted city and county to become the sites for sampling. As collecting samples, the strategy of systematic sampling was applied that every third consumers who had exited from the grocery shopping stores was invited to fill out the questionnaires. A consent letter informing the confidential treatment of consumers' data was provided to the potential subjects in order to help them to make the decisions of whether to participate in the survey. On average, the participants took about 10 to $15 \mathrm{~min}$ to complete the questionnaires. After completion, they received a gift from the staffs 
as compensation. The sample size drawn from each targeted city or county was determined by their population ratios based on the census data published by the Department of Household Registration, Ministry of the Interior of Taiwan. A total of 390 valid questionnaires were complemented to meet the sample size required for reaching $95 \%$ confidence in the statistical results.

Table 2. Sampling sites determined by a multi-stage cluster sampling strategy.

\begin{tabular}{|c|c|c|c|c|}
\hline & City/County & District/Town & Vegetable Retail Channels & Sample Size \\
\hline \multirow{15}{*}{$\begin{array}{l}\text { Urban area } \\
(n=240)\end{array}$} & \multirow{3}{*}{ Taipei } & \multirow{3}{*}{ Neihu } & (Traditional market) Hu Kwang traditional market & 16 \\
\hline & & & (Supermarket) Ting Ho supermarket-Hu Shing store & 16 \\
\hline & & & (Department store) Day Lake department store & 16 \\
\hline & \multirow{3}{*}{ New Taipei } & \multirow{3}{*}{ Yonghe } & (Traditional market) Shi Zou traditional market & 23 \\
\hline & & & (Supermarket) Ting Ho supermarket-Zoo Lin second store & 23 \\
\hline & & & (Department store) Pacific Ocean department store & 23 \\
\hline & \multirow{3}{*}{ Taichung } & \multirow{3}{*}{ West } & (Traditional market) Do Shing traditional market & 14 \\
\hline & & & (Supermarket) Fong Kong supermarket-Chung Ming store & 14 \\
\hline & & & (Department store) SHIN KONG MITSUKOSHI-Taichung store & 14 \\
\hline & \multirow{3}{*}{ Tainan } & \multirow{3}{*}{ Annan } & (Traditional market) HerShing traditional market & 10 \\
\hline & & & (Supermarket) Ting Ho supermarket-Annan store & 10 \\
\hline & & & (Department store) SHIN KONG MITSUKOSHI-Chung Shan store & 10 \\
\hline & \multirow{3}{*}{ Kaohsiung } & \multirow{3}{*}{ Sanmin } & (Traditional market) Po I traditional market & 17 \\
\hline & & & (Supermarket) Ting Ho supermarket-Da Fong store & 17 \\
\hline & & & (Department store) HanShin department store & 17 \\
\hline \multirow{8}{*}{$\begin{array}{c}\text { Non-urban area } \\
\quad(n=150)\end{array}$} & \multirow{2}{*}{ Miaoli } & \multirow{2}{*}{ Nanzhuang } & (Traditional market) Miaoli County public traditional market & 32 \\
\hline & & & (Supermarket) Ting Ho supermarket-Bay Miao store & 32 \\
\hline & \multirow{2}{*}{ Changhua } & \multirow{2}{*}{ Lukang } & (Traditional market) The First traditional market & 14 \\
\hline & & & (Supermarket) Fong Kong supermarket-LuKung store & 14 \\
\hline & \multirow{2}{*}{ Yunlin } & \multirow{2}{*}{ Beigan } & (Traditional market) Bay Kung traditional market & 20 \\
\hline & & & (Supermarket) Chang Lan supermarket-Bay Kung store & 20 \\
\hline & \multirow{2}{*}{ Taitung } & \multirow{2}{*}{ Chishang } & (Traditional market) Taitung public traditional store & 9 \\
\hline & & & (Supermarket) Chishang farmers' association supermarket & 9 \\
\hline
\end{tabular}

\subsection{Questionnaire Design}

Questionnaires were used as the instrument for data collection. There were four sections on the questionnaires developed based on the study objectives. The first section was aimed to measure consumer perception and concerns about the vegetables cultivated with plant factories. The first question is about consumers' perceptions for plant factory vegetables: "In your thought, what types of vegetables do you think the vegetables cultivated from plant factories are?" The second question relates to subjects' suspicions regarding growing vegetables with the approach of plant factories. This question helps the researcher in analyzing any potential obstacles to promoting plant factory vegetables. The question is: "Do you have any suspicion about the vegetables that are grown from plant factories?" If the subject gave the answer of 'Yes', they needed to respond to the associated follow-up questions to identify the details of the suspicions. The third question was designed to investigate subjects' level of acceptance of plant factory vegetables produced by different institutes. This is of interest because in the case of Asia most of the plant factories are invested by organizations, such as IT (information technology) industry firms, research institutions, or agribusiness organizations, instead of individual farmers. The question is worded "Which of the following institute's plant factory vegetables would you be most willing to buy?" All of the above were measured with a category scale.

The second section was aimed at investigating consumers' purchase intention and the reasons for buying or not buying the vegetables cultivated with plant factories. The question wording is: "Will you buy vegetables which are produced by a plant factory in the future?" Three possible conditions were listed for the subjects to indicate their answers, including (1) "Yes, I will," (2) "It depends," and (3) "No, I will not." As the subjects picked their answers, they needed to respond to the next question to indicate the reasons for their answers. The measures for this section were also in category scale.

The maximum price which consumers were willing to pay for plant factory vegetables was measured in the fourth section. In real market practice, prices for vegetables vary widely by species or variety, as well as based on supply and demand. Therefore, three most typical plant factory 
vegetables, i.e., lettuce of the varieties Lactuca sativa $\mathrm{L}$. var. longifolia and Lactuca sacriola $\mathrm{L}$. var. sativa bisch, as well as cabbage of the Brassica campestris L. var. chinensis variety, being communicated using their common names of "celery lettuce," "garden lettuce," and "bok choy" to consumers in the survey, were used as examples to measure the maximum price subjects were willing to pay for each kind of these plant factory vegetables under three different kinds of brand conditions, i.e., the independent brand of private organizations or academic institutes, as well as the allied brand of private organizations and academic institutes. Since academic institutes and private profit organizations are currently the main investors in the business of plant factories in the case of Asia, the maximum price consumers were willing to pay for the plant factory vegetables labeled with the brands of those organizations was measured in this study. This study design reflected the real current industry condition at the time. At the time of measuring, the recent highest and lowest retailing prices for the vegetables evaluated were given to the subjects for reference. These reference prices were obtained from researcher's weekly price checking with vegetable retailers. The work of price checking was carried out continuously for two months before the survey started.

The lowest reference prices all came from retail prices at a conventional market for the vegetables grown with the approach of conventional agriculture, while the highest reference prices were the retail prices from a supermarket located at department stores for the ones grown with the approach of organic agriculture. This information was also provided to the subjects. Thus, the subjects had been clearly told that for the vegetables of celery lettuce (Lactuca sativa L. var. longifolia), the lowest price was NT\$ (New Taiwanese Dollar) 42.5/kg for conventionally grown ones at a traditional market, while the highest was NT\$160.0/kg for the organic retail price of a super market at a department store. Similarly, the conventional versus organic reference prices of NT\$ $41.7 / \mathrm{kg}$ and NT\$ $144.0 / \mathrm{kg}$, respectively, were given to the subjects to refer as they were asked to indicate the maximum price they were willing to pay for the plant factory vegetable of garden lettuce (Lactuca sacriola $\mathrm{L}$. var. sativa bisch), while NT\$ $31.3 / \mathrm{kg}$ and NT\$144.0/kg were given for measuring the maximum price the subjects were willing to pay for the plant factory vegetable of bok choy (Brassica campestris L. var. chinensis).

The questionnaires also recoded consumers' socio-demographics, including their gender, age, education, and monthly income. Consumers' purchase behaviors for vegetables in terms of the money they spend weekly in purchasing both the general and organic vegetables were also recoded.

\subsection{Statistical Analysis}

Descriptive statistical analysis was used to analyze the distribution of subjects' socio-demographics, perception and concerns toward the vegetables grown with sustainable plant factory systems, as well as consumers' reasons for buying or not buying plant factory vegetables.

The influence of brand modes for consumers' willingness to pay for plant factory vegetables was analyzed with analysis of variance (ANOVA), followed by Duncan's post hoc analysis, to explore the branding mode that attracts higher consumers' willingness to pay for the vegetables grown with plant factories [31].

The influence of consumers' socio-demographics and purchase behaviors for vegetables on their willingness to pay for plant factory vegetables was also analyzed in this study with multiple regression analysis. Both socio-demographics and purchase behaviors are common variables for market segmentation, allowing marketers to identify the appropriate consumer segments to serve with [32]. Findings from this regression analysis allow the industry participants to identify the consumer groups who are more willing to pay for plant factory vegetables, being helpful for the market development of both the technology and crops of plant factories. Variables measured in category scales, such as gender, education, and income, were transformed into dummy variables before processed with regression analysis [31]. 


\section{Results and Discussion}

\subsection{Profile of Sample}

A total of 390 questionnaires were valid for statistical analysis. The sample consists of $25.1 \%$ men and $74.9 \%$ women, aged 18 to 73 years old. Over $58.2 \%$ of the subjects have a college or higher education degree. The sample was also highly diverse in jobs, and able to represent the highly diverse occupations in Taiwan [33]. The distribution of subjects' socio-demographics is presented at Table 3.

Table 3. Subject's socio-demographic profiles.

\begin{tabular}{|c|c|c|c|}
\hline Question & Choice Categories & Frequency $(n=390)$ & Percentage (\%) \\
\hline \multirow{2}{*}{ Gender } & Male & 98 & 25.1 \\
\hline & Female & 292 & 74.9 \\
\hline \multirow{6}{*}{ Age } & $18-27$ & 52 & 13.3 \\
\hline & $28-37$ & 82 & 21.0 \\
\hline & $38-47$ & 97 & 24.9 \\
\hline & $48-57$ & 102 & 26.1 \\
\hline & $58-67$ & 40 & 10.3 \\
\hline & 68 or over & 17 & 4.3 \\
\hline \multirow{4}{*}{ Education } & Junior high school or less & 42 & 10.8 \\
\hline & Senior high school & 121 & 31.0 \\
\hline & College & 201 & 51.5 \\
\hline & Graduate school & 26 & 6.7 \\
\hline \multirow{13}{*}{ Occupation } & Managers & 15 & 3.8 \\
\hline & Specialists & 19 & 4.9 \\
\hline & Administration service staffs & 48 & 12.3 \\
\hline & Sales & 97 & 24.9 \\
\hline & Agricultural, forestry, fishery, and husbandry production & 1 & 0.3 \\
\hline & Artistic workers & 11 & 2.8 \\
\hline & Engineers & 8 & 2.1 \\
\hline & Technicians & 20 & 5.1 \\
\hline & Government staffs & 45 & 11.5 \\
\hline & Homemakers & 85 & 21.8 \\
\hline & Students & 19 & 4.9 \\
\hline & The retired & 18 & 4.6 \\
\hline & Self-employed & 4 & 1.0 \\
\hline \multirow{4}{*}{ Monthly income } & NT\$ 40,000 or less & 116 & 29.7 \\
\hline & NT\$ 40,001-60,000 & 103 & 26.4 \\
\hline & NT\$ 60,001-80,000 & 81 & 20.8 \\
\hline & NT\$ 80,001 or more & 90 & 23.1 \\
\hline
\end{tabular}

\subsection{Consumer Perceptions and Suspicions toward the Plant Factory Vegetables}

The descriptive statistical analysis revealed that over half of the subjects perceived those vegetables as organic crops (54.9\%), even though they are not organic according to the definition of organic agriculture. "Safe" and "non-toxic" were other common perceptions that the subjects had for those vegetables, for respectively about $48.7 \%$ and $40.5 \%$ of the subjects. The terms "organic," "safe," and "non-toxic" imply the meaning of "safe" or "healthy" on eating for consumers. The subjects seem to be able to recognize the product value on food safety created by plant factory systems (Table 4).

However, $64.4 \%$ of the subjects indicated that they worried about the use of plant factories. The most worrying issue was regarding environmental pollutions: about $44.6 \%$ of the subjects worried whether the waste of the hydroponic solution in the plant factory systems would pollute the environment if it was released to the outside, and $42.2 \%$ of the subjects worried about whether the operation of pant factories would consume too much electricity, increasing the carbon footprint of the crops. Other concerns were in the areas of nature, dietary hygiene, and food nutrition: $31.9 \%$ of the subjects thought that the vegetables grown with plant factories were too "artificial," due to being cultivated with man-made systems, such as artificial lighting and automated IT systems. In these subjects' mind, it is the cultivation approach that greatly deviates it from nature. Another $30.3 \%$ of the subjects worried about micro-organism contamination for those vegetables. In addition, $26.7 \%$ of the subjects were 
concerned that the nutritional value of those vegetables might be lower compared with the vegetables grown with conventional agriculture approaches. A few of the subjects $(13.9 \%)$ disliked those vegetables since they did not like any vegetables grown with hydroponic systems.

Table 4. Consumer perception and suspicions about the vegetables cultivated with fully enclosed plant factories.

\begin{tabular}{|c|c|c|c|c|}
\hline Questions & & Choice Categories & Frequency $(n=390)$ & Percentage $(\%)$ \\
\hline \multirow{6}{*}{$\begin{array}{l}\text { In your thought, what } \\
\text { types of vegetables do } \\
\text { you think the vegetables } \\
\text { cultivated from plant } \\
\text { factories are? }\end{array}$} & 1) & Organic vegetables & 214 & 54.9 \\
\hline & 2) & Safe vegetables & 190 & 48.7 \\
\hline & 3) & Non-toxic vegetables & 158 & 40.5 \\
\hline & 4) & Hydroponic vegetables & 130 & 33.3 \\
\hline & 5) & High-tech vegetables & 73 & 18.7 \\
\hline & 6) & Conventional vegetables & 30 & 7.7 \\
\hline \multirow{8}{*}{$\begin{array}{l}\text { Do you have any suspicion } \\
\text { about the vegetables that } \\
\text { are grown from } \\
\text { plant factories? }\end{array}$} & $\begin{array}{l}\text { No } \\
\text { Yes }\end{array}$ & Multiple-Choice) & $\begin{array}{l}139 \\
251\end{array}$ & $\begin{array}{l}35.6 \\
64.4\end{array}$ \\
\hline & 1) & $\begin{array}{l}\text { Waste from the cultivation system, such as the nutrient } \\
\text { solution, of a plant factory may pollute the environment. }\end{array}$ & 112 & 44.6 \\
\hline & 2) & $\begin{array}{l}\text { Too much energy is consumed during the process } \\
\text { of production. }\end{array}$ & 106 & 42.2 \\
\hline & 3) & $\begin{array}{l}\text { Growing vegetables with plant factory technology } \\
\text { is unnatural. }\end{array}$ & 80 & 31.9 \\
\hline & 4) & $\begin{array}{l}\text { There may be bacteria contamination on the vegetables } \\
\text { grown from plant factories. }\end{array}$ & 76 & 30.3 \\
\hline & 5) & $\begin{array}{l}\text { The nutrition contents might be lower than } \\
\text { conventional vegetables. }\end{array}$ & 67 & 26.7 \\
\hline & 6) & $\begin{array}{l}\text { I do not like hydroponics vegetables, the same as } \\
\text { the plant-factory vegetables. }\end{array}$ & 35 & 13.9 \\
\hline & 7) & Others & 12 & 4.8 \\
\hline \multirow{5}{*}{$\begin{array}{l}\text { Which of the following } \\
\text { institute's plant factory } \\
\text { vegetables would you } \\
\text { be most willing to buy? }\end{array}$} & 1) & Government research institutes & 223 & 57.2 \\
\hline & 2) & Companies in agricultural business & 102 & 26.2 \\
\hline & 3) & Academic institutions & 53 & 13.6 \\
\hline & 4) & Companies in electronics technology industry & 6 & 1.5 \\
\hline & 5) & Private corporations & 6 & 1.5 \\
\hline
\end{tabular}

When being asked about their acceptance of the vegetables produced by different organizations' plant factories, most of the subjects (57.2\%) claimed to prefer those that were produced by government research institutes, rather than by corporations in agriculture business $(26.2 \%)$, academic institutes (13.6\%), e-technology companies $(1.5 \%)$, or private corporations $(1.5 \%)$.

\subsection{Reasons for Buying or Not Buying Plant Factory Vegetables}

The statistical analysis revealed that approximately $51.5 \%$ of the subjects were willing to buy the vegetables cultivated with plant factories, whereas $47.0 \%$ were unsure, and $1.5 \%$ were not willing to buy them at all.

For the subjects who were willing to buy, freedom from pesticide contamination and curiosity were the main reasons driving them to buy. Namely, $63.7 \%$ of the subjects were willing to buy based on the reason of no pesticide contamination, and $46.8 \%$ were willing based on curiosity. "Healthier," namely, better for health, was another important reason for the subjects being willing to buy the vegetables grown with plant factories (32.8\%). Other reasons for buying were chosen by a minority, including that the subjects perceived plant factory vegetables as more nutritious $(19.4 \%)$, fresher $(21.4 \%)$, 
better for environmental protection $(16.9 \%)$, having good appearance $(6.0 \%)$, higher quality $(8.0 \%)$, or tastier $(5.0 \%)$.

Among the entire sample, $47.0 \%$ of the subjects were unsure if they would buy the vegetables or not. Among those who were unsure, $72.1 \%$ of the participants indicated that their purchase intention would depend on whether the price was affordable, and $52.5 \%$ of the participants were uncertain due to not knowing where to buy them, while $44.3 \%$ of the participants indicated that they needed more information about the vegetables to be able to make a decision. Additionally, $42.6 \%$ preferred to have a free sample to try before they decided to buy, and $41 \%$ of the participants indicated that they needed more information regarding plant factory technology to decide whether to buy or not. In total, $25.7 \%$ of the subjects indicated that they were more used to consuming the vegetables cultivated with conventional agricultural production approaches (Table 5).

Table 5. Consumer purchase intentions for the vegetables cultivated with fully enclosed plant factories.

\begin{tabular}{|c|c|c|c|c|c|}
\hline & & & Reasons & Frequency & Percentage $(\%)$ \\
\hline & & 1) & No pesticide residue & 128 & 63.7 \\
\hline & Yes, I will. & 2) & Curious & 94 & 46.8 \\
\hline & $(n=201,51.5 \%)$ & 3) & Healthier & 66 & 32.8 \\
\hline & & 4) & Fresher & 43 & 21.4 \\
\hline & & 5) & More nutritious & 39 & 19.4 \\
\hline & & 6) & Friendlier to the environment & 34 & 16.9 \\
\hline & & 7) & Higher quality & 16 & 8.0 \\
\hline & & 8) & Good appearance & 12 & 6.0 \\
\hline & & 9) & More tastier & 10 & 5.0 \\
\hline Will you buy vegetables & & 10) & Others & 5 & 2.5 \\
\hline $\begin{array}{l}\text { which are produced by a } \\
\text { plant factory in the future? }\end{array}$ & & 1) & It depends on the price. & 132 & 72.1 \\
\hline & It depends. & 2) & Do not know where to buy them. & 96 & 52.5 \\
\hline & $(n=183,47.0 \%)$ & 3) & $\begin{array}{l}\text { Do not have enough product information } \\
\text { to make a decision. }\end{array}$ & 81 & 44.3 \\
\hline & & 4) & Need to try free samples to make decisions. & 78 & 42.6 \\
\hline & & 5) & $\begin{array}{l}\text { Do not understand the cultivation techniques } \\
\text { of plant factories. }\end{array}$ & 75 & 41.0 \\
\hline & & 6) & $\begin{array}{l}\text { Am used to buying the ordinary vegetables } \\
\text { grown conventionally. }\end{array}$ & 47 & 25.7 \\
\hline & & 1) & The cultivation method is unnatural & 4 & 66.7 \\
\hline & No, I will not. & 2) & It might be too expensive. & 2 & 33.3 \\
\hline & & 3) & Not safe & 2 & 33.3 \\
\hline & & 4) & $\begin{array}{l}\text { Do not trust the nutritional } \\
\text { value of the vegetables grown } \\
\text { from hydroponic systems. }\end{array}$ & 1 & 16.7 \\
\hline & & 5) & Tasteless & 1 & 16.7 \\
\hline
\end{tabular}

Another $1.5 \%$ of subjects expressed that they would definitely not buy the vegetables grown with plant factories. The main reasons are that they perceived the cultivation method of plant factories as unnatural, the price might be high, the vegetables might be unsafe, etc.

\subsection{Consumer Maximum Willingness to Pay}

The maximum price consumers were willing to pay for each kind of branded plant factory vegetables are presented in the boxplots in Figures 1-3. From the analysis of boxplots, the 25th through 75 th percentiles were focused on the range of about 2.2 to $5 \times$ the lowest prices, no matter what the brand is. For the vegetables of Lactuca sativa L. var. longifolia and Lactuca sacriola L. var. sativa bisch, no matter 
what the brand was, the 25th through 75th percentiles of the maximum price consumers were willing to pay ranged from NT\$ 50.01 to NT\$ 83.35 per $\mathrm{kg}$, and ranged from NT\$ 36.67 to NT\$ 83.35 per $\mathrm{kg}$ for the vegetable of Brassica campestris L. var. chinensis. Most of the consumers expressing the lowest willingness to pay gave prices around NT\$ 16.67 to NT\$20.00, while those with the highest willingness to pay cited costs of around NT\$ 158.37 to NT\$250.05 per $\mathrm{kg}$. The difference in the maximum price consumers were willing to pay for plant factory vegetables tended to be small across different brands.

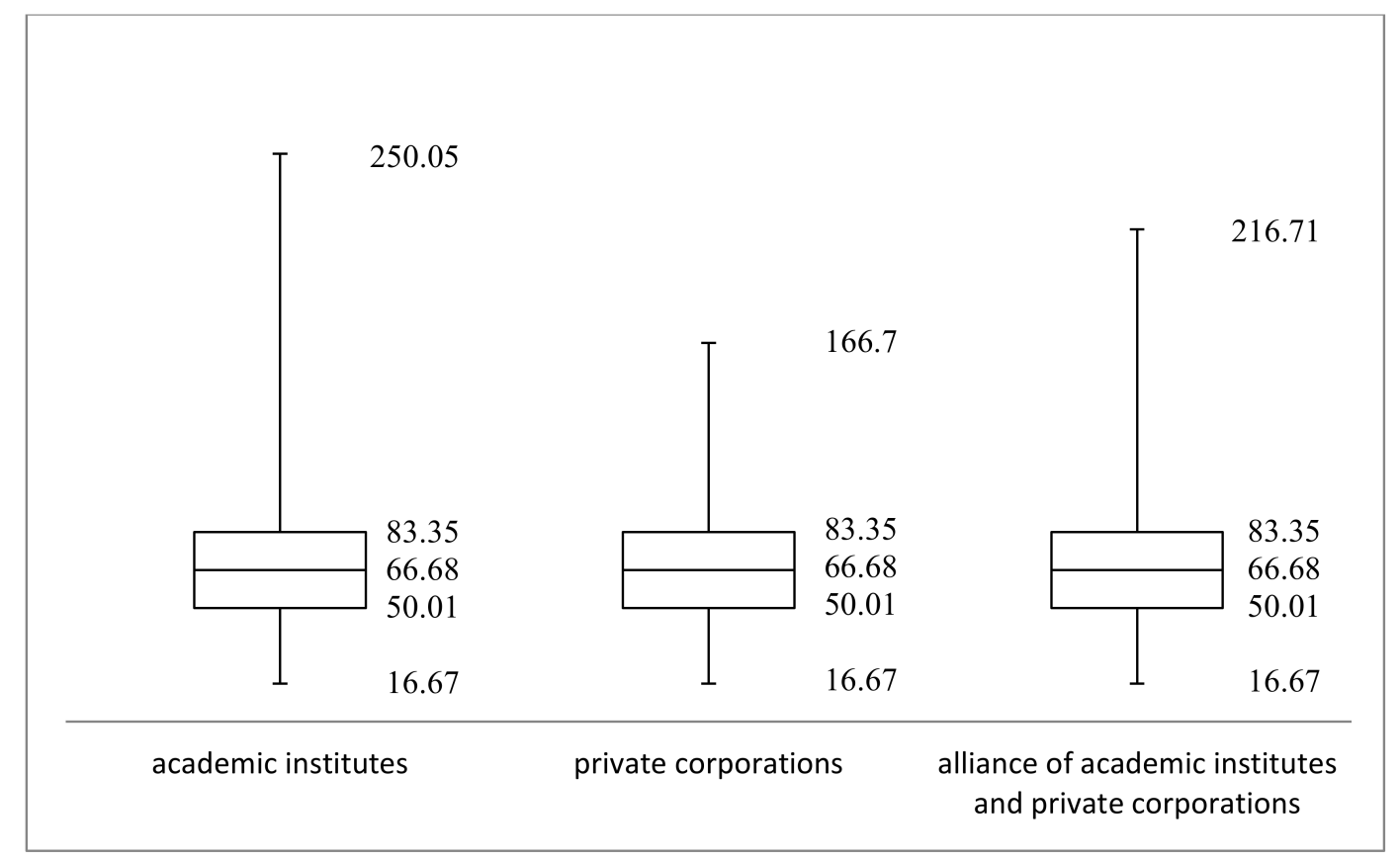

Figure 1. Consumer maximum willingness to pay for plant factory vegetables of Lactuca sativa $\mathrm{L}$. var. longifolia branded by different organizations (Measured in the unit of NT\$/kg).

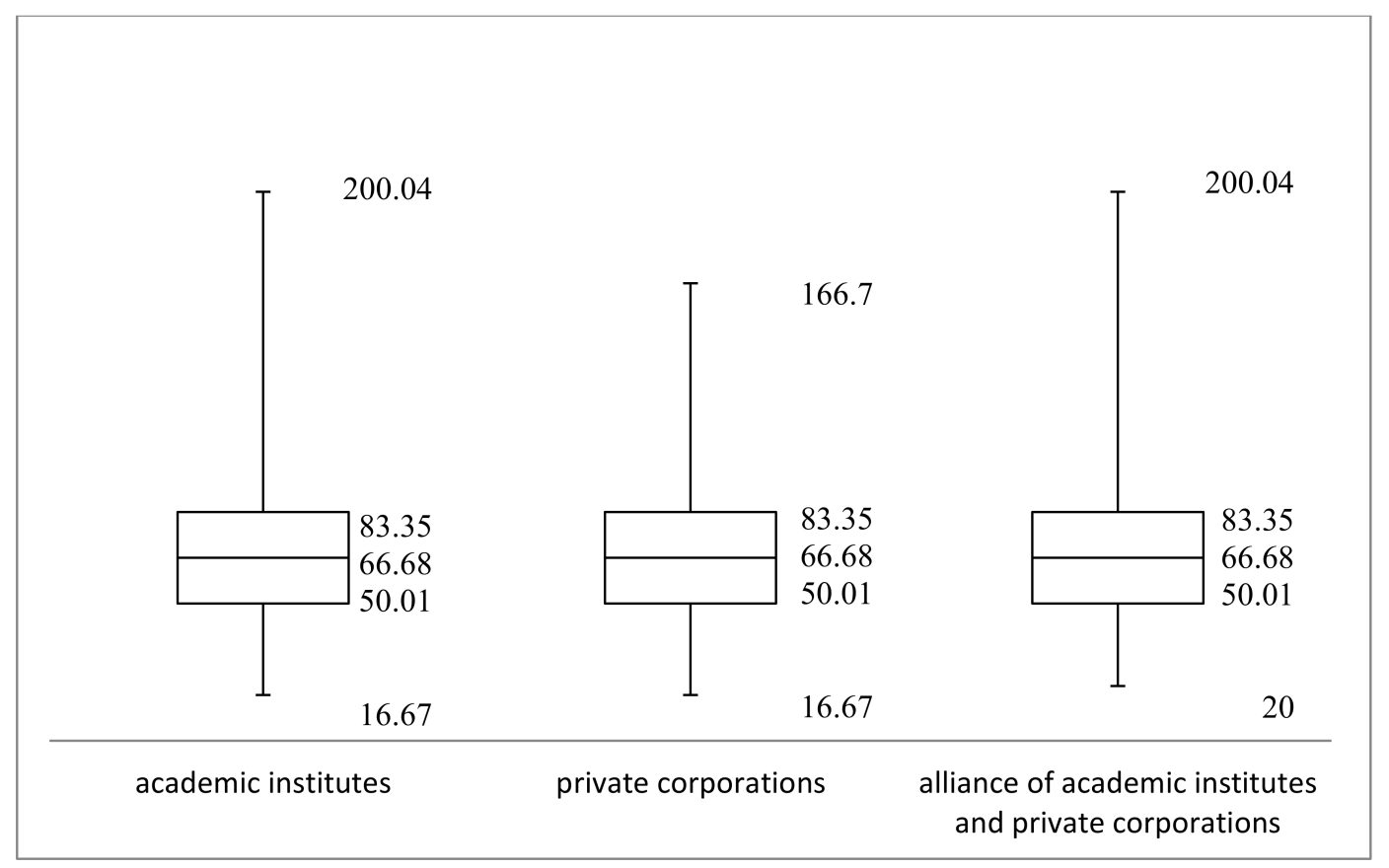

Figure 2. Consumer maximum willingness to pay for plant factory vegetables of Lactuca sacriola L. var. sativa bisch branded by different organizations (measured in the unit of NT\$/kg). 


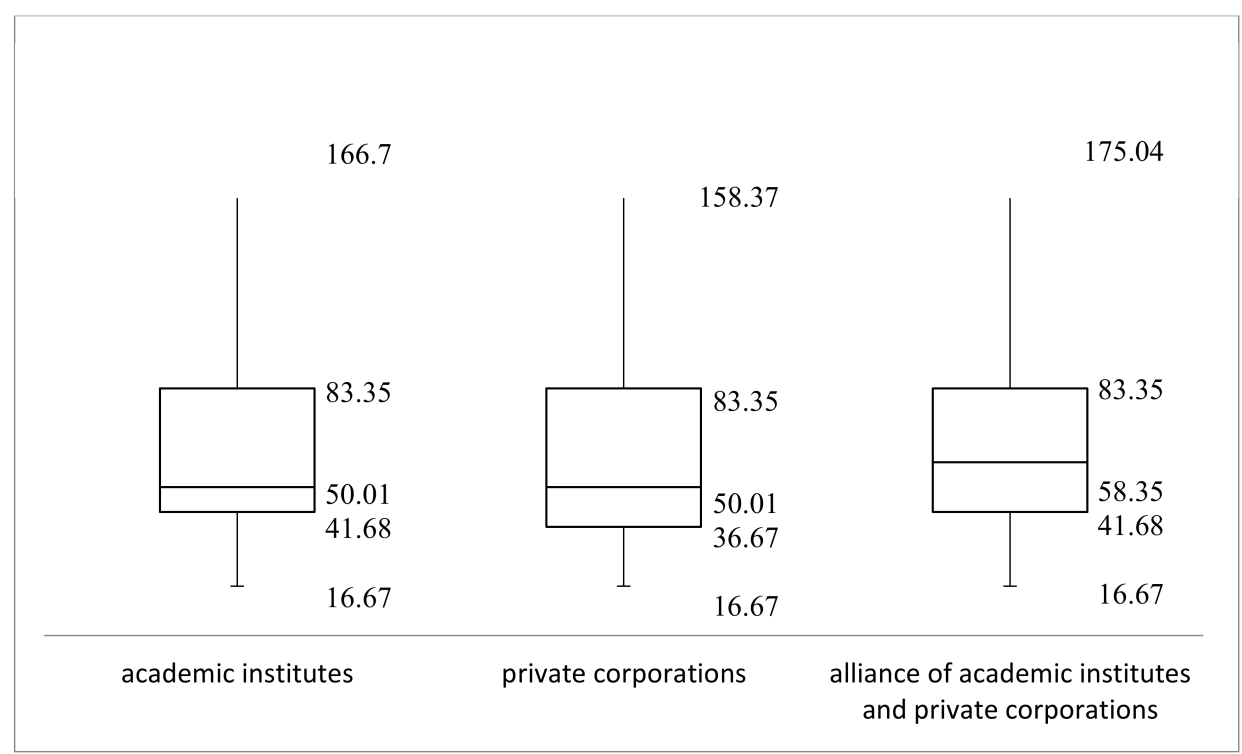

Figure 3. Consumer maximum willingness to pay for plant factory vegetables of Brassica campestris $\mathrm{L}$. var. chinensis branded by different organizations (measured in the unit of NT\$/kg).

For the vegetables of Lactuca sativa L. var. longifolia and Lactuca sacriola L. var. sativa bisch, the statistical results of the analysis of variance and Duncan's post hoc analysis revealed that the vegetables branded with the allied brand of the academic institutes and private corporations gained the highest willingness to pay from consumers, as presented in Table 6. The maximum price consumers were willing to pay for the vegetables with allied brands was significantly higher compared with that for the vegetables branded independently with private corporations. The maximum willingness to pay was about equal for the brands of the private organizations and academic institutes. However, for the vegetable of Brassica campestris L. var. chinensis, the difference of the maximum price consumers were willing to pay was not significant among the brands tested in this study. Even though the effect of brands on consumers' willingness to pay for plant factory vegetables varied across cultivars, on average, consumers were willing to pay more for plant factory vegetables branded with an allied brand of private corporations and academic institutes.

Table 6. Duncan's post hoc multiple comparison analysis for consumer maximum willingness to pay ${ }^{z, y}$.

\begin{tabular}{|c|c|c|c|c|c|}
\hline & $\begin{array}{c}\text { Private } \\
\text { Corporations }\end{array}$ & $\begin{array}{l}\text { Academic } \\
\text { Institutes }\end{array}$ & $\begin{array}{l}\text { Alliance of Private } \\
\text { Corporations and } \\
\text { Academic Institutes }\end{array}$ & $F$ & $P$ \\
\hline Lactuca sativa L. var. longifolia & $71.3^{\mathrm{a}}$ & $75.8^{\mathrm{b}}$ & $76.8^{\mathrm{b}}$ & 3.67 & $0.000 * *$ \\
\hline Lactuca sacriola L. var. sativa Bisch & $69.1^{\mathrm{a}}$ & $72.8^{a, b}$ & $74.3^{\mathrm{b}}$ & 3.55 & 0.029 * \\
\hline Brassica campestris L. var. chinensis & 57.4 & 60.6 & 62.5 & 2.96 & 0.052 \\
\hline Average & $65.9^{a}$ & $69.7^{\mathrm{a}, \mathrm{b}}$ & $71.2^{b}$ & 3.53 & $0.030 *$ \\
\hline
\end{tabular}

$p<0.001{ }^{* *}, p<0.05^{*} ;{ }^{\mathrm{z}}$ Measured in the unit of NT\$ $/ \mathrm{kg} ;{ }^{\mathrm{y}}$ Mean scores with different alphabets in each row differ significantly at $\alpha=0.05$.

Furthermore, the statistical results of regression analysis indicated that consumers' socio-economics and vegetable purchase behaviors also influenced consumers' willingness to pay for the plant factory vegetables. It was found that consumers who have a higher income or consume more organic vegetables in their daily lives were more willing to pay for the vegetables grown in plant factories (Table 7). Higher income increases consumers purchase power. This may be the reason that consumers with higher income were more willing to pay for plant factory vegetables. Organic vegetables are usually perceived as more expensive, but more environmentally friendly or safer to human's health compared with those produced with conventional agriculture production systems [34]. Therefore, for those who are more likely to consume organic vegetables, they may have higher safe awareness for foods, and thus, they may be more likely to value the characteristic of pesticide-free of plant factory 
vegetables [35]. Moreover, it was reported that organic consumers are relatively less price sensitive [36]. Those described above may explain the finding of this study that the consumers who consume more organic vegetables are more willing to pay for the plant factory vegetables.

Table 7. The statistical results of regression analysis regarding the influence of consumers' socio-demographics and vegetable purchase behaviors for their maximum willingness to pay for the vegetables grown with plant factories.

\begin{tabular}{|c|c|c|c|c|c|}
\hline \multirow{2}{*}{ Variables } & \multicolumn{2}{|c|}{ Unstandardized } & \multirow{2}{*}{$\begin{array}{c}\text { Standardized } \\
\beta\end{array}$} & \multirow[b]{2}{*}{$t$} & \multirow{2}{*}{$p$} \\
\hline & $\beta$ & Standard Error & & & \\
\hline (constant) & 45.978 & 2.879 & & 15.973 & 0.000 \\
\hline Gender ${ }^{z}$ & -0.104 & 1.884 & -0.003 & -0.055 & 0.956 \\
\hline Age & -0.082 & 0.067 & -0.067 & -1.219 & 0.224 \\
\hline Education $\mathrm{y}$ & -0.974 & 1.846 & -0.029 & -0.528 & 0.598 \\
\hline Income $^{x}$ & -3.929 & 1.830 & -0.109 & -2.147 & $0.032^{* *}$ \\
\hline Money spent in general vegetable consumption & -0.003 & 0.002 & -0.118 & -1.695 & 0.091 \\
\hline Money spent in organic vegetable consumption & 0.015 & 0.004 & 0.260 & 3.715 & $0.000^{*}$ \\
\hline
\end{tabular}

* Significant at $p<0.01 ;{ }^{* *}$ Significant at $p<0.05 .{ }^{2}$ A dummy variable where "male" equals "1," otherwise

" 0 "; " A dummy variable that the education level of "senior high school or lower" equals " 1 ," otherwise " 0 ";

“ A dummy variable that monthly income of "NT\$ 40,000 or less" equals " 1 ," otherwise "0".

\section{Conclusions}

This study aimed to explore the market potential of sustainable plant factory production systems with the measurements of consumers' recognition, concerns, purchase intentions, maximum willingness to pay, and brand preference for the vegetables cultivated with plant factories. The study results reveal that generally, consumers can recognize the product value created via the sustainable plant factory production systems for crops, namely "food safety," being supported by the findings in this study that consumers generally perceived the plant factory vegetables as "safe" and "non-toxic." Some consumers even perceived those vegetables as "organic," even though this was not the case. It is also supported by the finding that for those who are willing to buy plant factory vegetables, "no pesticide residue" and "good for health" were the main factors motivating these consumers to buy the vegetables. Obviously, consumers understand the value of plant factories, in that they know that they can grow safe and high-quality crops. This finding is consistent with the result of previous study conducted by You et al. [37]. They compared the informational and emotional appeals of logo design for consumers' purchase intentions for plant-factory-produced vegetables and found that feelings of safety were the strongest factor that drives consumers' purchase intentions.

However, over half of the consumers (64.4\%) revealed concerns about the crops and technology of plant factories. The most frequently mentioned concerns were raised from the view point of environmental protection, regarding whether the plant factory systems are too energy-consuming or would cause pollution to the environment. This is a new finding beyond previous studies. As previous studies discussed the influence of consumer concerns for the purchase intentions of plant factory vegetables, they mostly focused on the concerns about utility functions, such as price, nutritional value, pesticide application, etc. How consumers' environmental concerns affect their perceptions and attitudes toward plant factory vegetables were rarely investigated [37-39]. As plant factories are positioned as a sustainable agricultural production system, how consumers' environmental attitudes influence their purchase intentions for plant factory vegetables should not be ignored as we discuss the development of plant factory industry. This study also found some minor concerns related to consumers' individual benefits, such as whether microorganism contamination occurs on the vegetables grown with the approach of plant factories, or whether plant factory vegetables have lower nutritional value than the conventional ones. These concerns need to be assuaged to increase consumer acceptance when promoting the plant factory vegetables.

Nearly half of the consumers $(47.0 \%)$ were uncertain whether to adopt plant factory vegetables or not. The main reason for their uncertainty was the concern of price. As high as $72.1 \%$ of those consumers indicated that whether they would buy the factory-grown vegetables would depend 
on the price of those vegetables. This finding is consistent with previous studies conducted with the consumers in Singapore and Japan, i.e., consumers' purchase intentions for plant factory vegetables are highly price-dependent $[37,38]$. Therefore, in terms of the scientific research of plant factory production systems, scientists should contribute more efforts on how to reduce the operation cost of plant factories from multiple aspects [40], such as the use efficiency of various production resources [41,42]. Once the production cost can be reduced, the retailing price of plant factory vegetables can become friendlier to consumers. Even though consumers have shown willingness to pay more for the vegetables grown with plant factories, good price value helps to increase the market competitiveness of those vegetables, and thus, it would be helpful to increase the popularity of the usage of plant factory technology in agricultural production.

A way to increase the price value of plant factory vegetables is to brand those products appropriately. The analysis of consumers' maximum willingness to pay indicates that consumers were more willing to pay for the plant factory vegetables that were co-branded with the names of both academic institutes and private corporations, compared with those that are branded with the name of a single organization of either academic institutes or private corporations. This also implies that co-branding with academic institutes seems to be a good marketing strategy for the private corporations to sell their plant factory vegetables. Beside the style of brands, this study also explored that the characteristics of consumers' socio-economics and purchase behaviors for organic vegetables also influence consumers' willingness to pay. Namely, consumers who have a higher income and/or consume more organic vegetables are more willing to pay for plant factory vegetables. The study results implied that the promotion of the plant factory vegetables should be targeted at the consumers who have higher income or consume more organic vegetables.

Overall, this study reveals several valuable findings regarding adopting plant factory systems into agricultural production:

1. Consumers can recognize the product value of "pesticide-free" for the crops grown with plant factories, and they perceive those crops as "safe" and "non-toxic," which can serve as the points for the market promotion of plant factory vegetables.

2. Even though plant factories are sustainable production systems from the perspectives of natural resource requirement and pesticide application for agricultural production, some consumers reveal the concerns of whether plant factories are too electricity-consuming or would cause any other pollution to the environment. This implies that the future research and development of plant factories should focus on the technology of electricity saving, as well as the consumer communication regarding whether other possible pollution exists for the use of plant factories.

3. Some consumers do not know much about plant factory vegetables, and therefore hesitate to buy them. This implies that for the future development of plant factories, the characteristics and product values generated from the usage of plant factory production systems need to be promoted.

4. Consumer purchase intentions for plant factory vegetables are price-sensitive. However, the format of brand influences consumers' willingness to pay for the plant factory crops. For the future development of plant factory technology, the researchers should aim at the topics of reducing its construction and operation costs, as well as the appropriate format for the name of the brand when commercializing the plant factory vegetables.

5. Consumers who have a higher income or consume more organic vegetables are more willing to pay higher prices. Thus, the promotion of plant factory vegetables should aim at those consumers.

Findings from this study are beneficial for us to explore consumer purchase behavior for the agricultural products cultivated from a sustainable production system that is equipped with high technology in environmental control. However, the business feasibility of this newly developed agriculture production system is not fully investigated. Future research is suggested to focus on this from the perspectives of commercial economics and environmental sustainability. 
Funding: This research was funded by the Ministry of Science and Technology and the Council of Agriculture of Taiwan.

Acknowledgments: The author would like to thank the anonymous reviewers and editors for their thoughtful comments and suggestions.

Conflicts of Interest: The author declares no conflict of interest.

\section{References}

1. Nichols, M. Plant factories-the ultimate in controlled environment agriculture. ICESC2015 Hydroponics Aquaponics Gold Coast 2015, 1176, 17-22. [CrossRef]

2. Shamshiri, R.R.; Kalantari, F.; Ting, K.C.; Thorp, K.R.; Hameed, I.A.; Weltzien, C.; Ahmad, D.; Shad, Z.M. Advances in greenhouse automation and controlled environment agriculture: A transition to plant factories and urban agriculture. Int. J. Agric. Biol. Eng. 2018, 11, 1-22. [CrossRef]

3. WinterGreen Research, Inc. Plant Factory Grow Lights and Control Systems Market Strategies, Shares and Forecasts, Worldwide, 2010-2016; WinterGreen Research, Inc.: Lexington, MA, USA, 2010.

4. Brammer, H.; Ravenscroft, P. Arsenic in groundwater: A threat to sustainable agriculture in South and South-east Asia. Environ. Int. 2009, 35, 647-654. [CrossRef]

5. Pei, X.; Tandon, A.; Alldrick, A.; Giorgi, L.; Huang, W.; Yang, R. The China melamine milk scandal and its implications for food safety regulation. Food Policy 2011, 36, 412-420. [CrossRef]

6. Prabhakar, S.V.R.K.; Sano, D.; Srivastava, N. Food Safety in the Asia-Pacific Region: Current Status, Policy Perspectives, and $a$ Way Forward; Institute for Global Environmental Strategies: Hayama, Japan, 2010.

7. Kozai, T. Resource use efficiency of closed plant production system with artificial light: Concept, estimation and application to plant factory. Proc. Jpn. Acad. 2013, 89, 447-461. [CrossRef]

8. Aydinalp, C.; Cresser, M.S. The effects of global climate change on agriculture. Am. Eurasian J. Agric. Environ. Sci. 2008, 3, 672-676.

9. Watanabe, H. Light-controlled plant cultivation system in Japan-Development of a vegetable factory using LEDs as a light source for plants. Acta Hortic. 2011, 907, 37-44. [CrossRef]

10. Boccaletti, S.; Nardella, M. Consumer willingness to pay for pesticide-free fresh fruit and vegetables in Italy. Int. Food Agribus. Manag. Rev. 2000, 3, 297-310. [CrossRef]

11. Cranfield, J.; Magnusson, E. Canadian consumer's willingness-to-pay for pesticide free food products: An ordered probit analysis. Int. Food Agribus. Manag. Rev. 2003, 6, 13-30.

12. Cranfield, J.; Henson, S.; Holliday, J. The motives, benefits, and problems of conversion to organic production. Agric. Hum. Values 2010, 27, 291-306. [CrossRef]

13. Chen, X.L.; Yang, Q.C.; Song, W.P.; Wang, L.C.; Guo, W.Z.; Xue, X.Z. Growth and nutritional properties of lettuce affected by different alternating intervals of red and blue LED irradiation. Sci. Hortic. 2017, 223, 44-52. [CrossRef]

14. Hwang, J. A Production Line for Plants. Taiwan Review. 2012. Available online: http://taiwanreview.nat.gov. tw/fp.asp?xItem $=182083 \&$ ctNode $=1337$ (accessed on 19 November 2013).

15. Shimizu, H.; Saito, Y.; Nakashima, H.; Miyasaka, J.; Ohdoi, K. Light Environment Optimization for Lettuce Growth in Plant Factory. In Proceedings of the 18th IFAC World Congress, Milano, Italy, 28 August-2 September 2011; pp. 605-609.

16. Gasteyer, S.P. Agricultural transitions in the context of growing environmental pressure over water. Agric. Hum. Values 2008, 25, 469-486. [CrossRef]

17. Son, J.E.; Park, J.S.; Lee, L. Development of urban-type plant factory for plant production and air purification. Acta Hort. 2002, 578, 257-262. [CrossRef]

18. Specht, K.; Siebert, R.; Hartmann, I.; Freisinger, U.B.; Sawicka, M.; Werner, A.; Thomaier, S.; Henckel, D.; Walk, H.; Dierich, A. Urban agriculture of the future: An overview of sustainability aspects of food production in and on buildings. Agric. Hum. Values 2014, 31, 33-51. [CrossRef]

19. Taylor, J.R.; Lovell, S.T. Urban home food gardens in the Global North: Research traditions and future directions. Agric. Hum. Values 2014, 31, 285-305. [CrossRef]

20. Lai, C.C.; Fang, W.; Chang, S.F. Plant factory in Taiwan using moving light with multi-layers. Acta Hort. 2002, 578, 263-267. [CrossRef]

21. Kim, J.W. Trend and direction for plant factory system. J. Plant Biotechnol. 2010, 37, 442-455. [CrossRef]

22. Lim, S.T.; Yang, S.R. Is plant factory a sustainable alternative? Korean J. Agric. Manag. Policy 2011, 38, 917-942. 
23. Watanabe, A. Plant factory business aiming for sustainable growth - Trends of entering companies and challenges to establish growth models (持続的成長を目指す植物工場ビジネス-参入企業の動向 と成長モデル確立への課題). Ind. Innov. 2010, 68, 1-16. (In Japanese)

24. Japan Finance Corporation. Consumer Awareness of Vegetables Grown in Plant Factories (植物工場で栽培される 野菜に関する消費者意識); Japan Finance Corporation: Tokyo, Japan, 2009. (In Japanese)

25. Glenna, L.L.; Jussaume, R.A., Jr.; Dawson, J.C. How farmers matter in shaping agricultural technologies: Social and structural characteristics of wheat growers and wheat varieties. Agric. Hum. Values 2011, 28, 213-224. [CrossRef]

26. Kruseman, G.; Bade, J. Agrarian policies for sustainable land use: Bio-economic modeling to assess the effectiveness of policy instruments. Agric. Syst. 1998, 58, 465-481. [CrossRef]

27. Wreford, A.; Renwick, A. Estimating the costs of climate change adaptation in the agricultural sector. Cab. Rev. 2012, 7, 1-10. [CrossRef]

28. Kato, K.; Yoshida, R.; Kikuzaki, A.; Hirai, T.; Kuroda, H.; Hiwasa-Tanase, K.; Mizoguchi, T. Molecular breeding of tomato lines for mass production of miraculin in a plant factory. J. Agric. Food Chem. 2010, 58, 9505-9510. [CrossRef]

29. Park, J.E.; Murase, H. Optimal Environmental Condition for Moss Production in Plant Factory System. In Proceedings of the 18th IFAC (International Federation of Automatic Control) World Congress, Milano, Italy, 28 August-2 September 2011; pp. 621-626.

30. Shimizu, H. Current Status and Challenge of Plant Factory in Japan. In Proceedings of the International Agriculture Engineering Conference, Bangkok, Thailand, 7-10 December 2009.

31. Hair, J.F., Jr.; Black, W.C.; Babin, B.J.; Anderson, R.E. Multivariate Data Analysis: A Global Perspective, 7th ed.; Prentice Hall: Upper Saddle River, NJ, USA, 2010.

32. Armstrong, G.; Kotler, P. Marketing: An Introduction; Pearson: Boston, MA, USA, 2013.

33. Council of Labor Affairs of Taiwan. The Salary Distribution for Occupations (In Chinese). Available online: https://pswst.cla.gov.tw/PSDN/Query/wFrmQuery01.aspx (accessed on 26 October 2013).

34. Vukasovič, T. Consumers' perceptions and behaviors regarding organic fruits and vegetables: Marketing trends for organic food in the twenty-first century. J. Int. Food Agribus. Mark. 2016, 28, 59-73. [CrossRef]

35. Zhang, B.; Fu, Z.; Huang, J.; Wang, J.; Xu, S.; Zhang, L. Consumers' perceptions, purchase intention, and willingness to pay a premium price for safe vegetables: A case study of Beijing, China. J. Clean. Prod. 2018, 197, 1498-1507. [CrossRef]

36. Aschemann-Witzel, J.; Zielke, S. Can't buy me green? A review of consumer perceptions of and behavior toward the price of organic food. J. Consum. Aff. 2017, 51, 211-251. [CrossRef]

37. You, Z.; Zhang, X.; Chen, C.H.; Ono, K.; Hibino, H.; Koyama, S. Impact of relevant knowledge on purchase intention of plant-factory-produced plants. Focus Mod. Food Ind. 2013, 2, 63-69.

38. Kurihara, S.; Ishida, T.; Suzuki, M.; Maruyama, A. Consumer evaluation of plant factory produced vegetables. Focus. Mod. Food Ind. 2014, 3, 1-9. [CrossRef]

39. You, Z.; Zhang, X.; Koyama, S. Informational vs. emotional appeals of logo design in influencing purchase intentions for plant-factory-produced vegetables. Int. J. Adv. Psychol. 2013, 2, 224-231. [CrossRef]

40. Sugimura, N.; Iwamura, K.; Thinh, N.; Nakai, K.; Fukumoto, S.; Tanimizu, Y. Production Cost Analysis and Production Planning for Plant Factories Considering Markets. In Proceedings of the IFIP International Conference on Advances in Production Management Systems, Tokyo, Japan, 7-9 September 2015; pp. 532-540.

41. Graamans, L.; Baeza, E.; Van Den Dobbelsteen, A.; Tsafaras, I.; Stanghellini, C. Plant factories versus greenhouses: Comparison of resource use efficiency. Agric. Syst. 2018, 160, 31-43. [CrossRef]

42. Kikuchi, Y.; Kanematsu, Y.; Yoshikawa, N.; Okubo, T.; Takagaki, M. Environmental and resource use analysis of plant factories with energy technology options: A case study in Japan. J. Clean. Prod. 2018, 186, 703-717. [CrossRef]

(C) 2019 by the author. Licensee MDPI, Basel, Switzerland. This article is an open access article distributed under the terms and conditions of the Creative Commons Attribution (CC BY) license (http://creativecommons.org/licenses/by/4.0/). 